\title{
Continued declines of black abalone along the coast of California: are mass mortalities related to El Niño events?
}

\author{
Peter T. Raimondi ${ }^{1}$, C. Melissa Wilson ${ }^{1}$, Richard F. Ambrose ${ }^{2}$, John M. Engle ${ }^{3}$, \\ Todd E. Minchinton ${ }^{1, *}$ \\ ${ }^{1}$ Department of Ecology and Evolutionary Biology, Long Marine Laboratory, 100 Shaffer Road, University of California, \\ Santa Cruz, California 95064, USA \\ ${ }^{2}$ Environmental Science and Engineering Program, Department of Environmental Health Sciences, PO Box 951772, \\ University of California, Los Angeles, California 90095-1772, USA \\ ${ }^{3}$ Marine Science Institute, University of California, Santa Barbara, California 93106, USA
}

\begin{abstract}
The intertidal black abalone Haliotis cracherodii has experienced mass mortalities along the coast of California, USA, since the mid-1980s. Mortality is due to infection by a pathogen that leads to a fatal wasting disease called 'withering syndrome', where the foot of the abalone atrophies until it can no longer adhere to the substratum. Massive die-offs due to withering syndrome were first noted on the Channel Islands in 1986, and by 1992 withering syndrome was observed near Point Conception on the mainland and was suspected to be spreading northward up the coast of California. The timing of the initial mass mortalities following the strong 1982 to 1983 El Niño and an isolated outbreak of withering syndrome in 1988 at Diablo Cove, north of Point Conception, following warm water discharge from a power plant, led to the hypothesis that the onset of mass mortalities due to withering syndrome may be triggered by elevated seawater temperatures. We surveyed black abalone populations at 7 sites along the mainland coast of California (including 3 where withering syndrome was already present) from 1992 to 2001, a period spanning 2 El Niño events, to determine whether (1) withering syndrome and associated declines of black abalone were spreading northward up the coast; and (2) these mass mortalities of black abalone could be related to elevated seawater temperatures during El Niño events. Mass mortalities of black abalone due to withering syndrome were observed at the 5 most southern sites (>90\% decline in numbers in all size classes), but not at the 2 most northern sites, and there was a clear pattern of decline from south to north over time. Massive die-offs of abalone were not exclusively associated with times of elevated sea surface temperatures due to El Niño. Nevertheless, rapid declines of abalone at 2 sites coincided with the strong 1997 to 1998 El Niño, and declines during El Niño events were faster than those during non-El Niño years. Abalone at the 2 most northern sites, where only slight declines occurred during the 1997 to 1998 El Niño, may not have been infected by disease. It appears, therefore, that in the presence of the pathogen, warm water conditions associated with El Niño may accelerate the development of withering syndrome and the rate of decline of black abalone. Consequently, anthropogenic disturbances, such as discharges of heated water or global warming, may increase the incidence of this fatal disease.
\end{abstract}

KEY WORDS: Withering syndrome $\cdot$ El Niño $\cdot$ Haliotis cracherodii $\cdot$ Human disturbance $\cdot$ Mass mortalities · Marine diseases $\cdot$ Intertidal zone

\section{INTRODUCTION}

${ }^{*}$ Corresponding author. Present address: Department of Environmental Biology, The University of Adelaide, South Australia 5005, Australia.

E-mail: todd.minchinton@adelaide.edu.au
Mass mortalities of marine organisms due to outbreaks of disease appear to be increasingly common throughout the world's oceans (Harvell et al. 1999). Along the coast of California, USA, the ecologically 
and once commercially important intertidal black abalone Haliotis cracherodii has suffered massive local die-offs (generally >90\% losses) since the mid-1980s (Davis et al. 1992, Steinbeck et al. 1992, Lafferty \& Kuris 1993, VanBlaricom et al. 1993, Altstatt et al. 1996). Mortality has been attributed to a chronic and fatal condition called 'withering syndrome' (Tissot 1990, Haaker et al. 1992, Gardner et al. 1995, Friedman et al. 1997). The most prominent features of this wasting disease in the field include reduced body mass, weakness and a withered foot which prevents the abalone from clinging to the substratum (Haaker et al. 1992, Richards \& Davis 1993).

Dying abalone with signs of withering syndrome were first observed on several of the Channel Islands off the coast of southern California in 1986 (Haaker et al. 1992, see Fig. 1). By 1992, withering syndrome and mass mortalities of black abalone had radiated throughout the Channel Islands (Tissot 1990, Davis et al. 1992, Richards \& Davis 1993, VanBlaricom et al. 1993). Along the mainland coast at this time, withering syndrome and die-offs of black abalone were observed at a single site, Diablo Cove in central California in 1988 (Steinbeck et al. 1992). Withering syndrome may have also been present during this time along the mainland coast south of Point Conception, but, because populations of black abalone were so small due to harvesting, the disease and associated mortalities may have gone undetected. In 1992, mass mortalities were again observed along the mainland coast, this time at a site near Point Conception, north of the Channel Islands and south of Diablo Cove (Altstatt et al. 1996). Subsequent monitoring by Altstatt et al. (1996) over the next 4 yr revealed that declines of black abalone were occurring at nearby sites to the north, and they suggested that withering syndrome might be progressing northward up the coast.

Explanations for the cause of withering syndrome have largely focused on the presence of pathogens, natural and anthropogenic environmental stresses, and their interactions. An initial hypothesis was that the disease was caused by thermal stress and starvation due to elevated seawater temperatures and reduced availability of food associated with El Niño events (Tissot 1990, 1995, Davis et al. 1992, Richards \& Davis 1993). This hypothesis was put forth because the disease and associated massive die-offs of black abalone were initially observed at the Channel Islands following the strong 1982 to 1983 El Niño and the weaker 1986 to 1987 El Niño. This explanation appeared to be supported when an isolated outbreak of withering syndrome and massive die-offs of black abalone were observed in 1988 at Diablo Cove on the mainland coast of California, where the thermal discharge of water from the Diablo Canyon Power Plant raised seawater temperatures up to $11^{\circ} \mathrm{C}$ above ambient (Steinbeck et al. 1992). The presence of potential pathogens and the geographic patterns of spread of the syndrome and mortalities on the Channel Islands and along the mainland coast of California provided evidence for an infectious agent as the cause of disease (Lafferty \& Kuris 1993, Altstatt et al. 1996). Recently, an intracellular bacterium, given the provisional status of 'Candidatus Xenohaliotis californiensis', that infects the epithelial cells of the gastrointestinal tract of black abalone, has been identified as the causative agent of withering syndrome (Friedman et al. 2000).

The pathogen and isolated cases of withering syndrome have now been observed in black abalone along the central and extending toward the northern coast of California, most notably at several sites where mass mortalities have yet to occur (Altstatt et al. 1996, Andree et al. 2000, authors' pers. obs.). Abalone may thus be infected with the bacterium before clinical signs of withering syndrome are evident in the field (Friedman et al. 1997, Andree et al. 2000) and the appearance of isolated cases of withered abalone may precede massive local die-offs. This lag between infection, the development of clinical withering syndrome and the onset of mass mortalities may represent an incubation period during which the bacteria grow to critical levels within the local population. Stressful environmental conditions, such as elevated water temperature or reduced food supply, may increase the susceptibility of abalone to disease, shorten the incubation period, increase the incidence of withering syndrome and accelerate the onset of mass mortalities of black abalone. Laboratory studies examining the effects of thermal stress and lack of food on black abalone have shown that neither appears to be the direct cause of withering syndrome (Steinbeck et al. 1992, Friedman et al. 1997). Nevertheless, elevated water temperatures appear to increase the rate of mortality of black abalone (Steinbeck et al. 1992, Lafferty \& Kuris 1993, Tissot 1995, Friedman et al. 1997, see also Moore et al. 2000 for studies with red abalone Haliotis rufescens). Therefore, as is increasingly documented for other marine species (see Harvell et al. 1999), mass mortalities of black abalone due to withering syndrome may be triggered by prolonged periods of above-average seawater temperatures, which are characteristic of El Niño events.

Here, we present the results of surveys at 7 sites documenting the continued mass mortalities (and lack of recovery) of populations of black abalone along the mainland coast of California, USA, for nearly a decade (1992 to 2001) spanning the El Niño events of 1991 to 1993 and 1997 to 1998 (Wolter \& Timlin 1998). Our first of 2 objectives was to determine whether withering syndrome and associated declines of black abalone 
were progressing northward up the coast as predicted by Altstatt et al. (1996). Our second objective was to assess whether these mass mortalities of black abalone could be related to elevated seawater temperatures during El Niño, particularly the 1997 to 1998 event, which was 1 of the 2 strongest of the last century (Wolter \& Timlin 1998). Surveys included 4 northern sites where withering syndrome had not been observed before the 1997 to 1998 El Niño event. We predicted that if El Niño triggered massive die-offs of black abalone, then abalone at these sites should decline simultaneously, as each site would experience the same mass of warm water. Other spatial patterns of decline would suggest the importance of alternative factors. Because this study includes before and after surveys of the abundance of black abalone at multiple sites following one of the strongest El Niño events of the last century, it provides the most rigorous test to date of the hypothesis that elevated seawater temperatures due to El Niño accelerate the decline of black abalone.

\section{MATERIALS AND METHODS}

Black abalone were monitored at 7 sites along the mainland coast of California, USA, from 1992 to 2001 (and also at 5 other sites, but only since 1999, therefore data are not presented) (Fig. 1). Four sites (Government Point, Boathouse, Stairs and Purisima Point) were established in 1992 to 1993. Data collected from these sites from 1992 to 1995 have been previously reported in Altstatt et al. (1996). The other 3 sites (Cayucos Point, Piedras Blancas and Point Sierra Nevada) were established in 1996 to 1997 and are located north of Diablo Cove, where the isolated outbreak of withering syndrome was observed in 1988. By the end of 1995, black abalone at the 2 most southern sites, Government Point and Boathouse, had already undergone massive die-offs due to withering syndrome, and this disease had also been detected at Stairs (Altstatt et al. 1996).

Sites were initially located within the intertidal zone on rocky shores where black abalone were abundant. Three permanent plots were established at each site. The sizes and shapes of plots varied within and among sites depending on the occurrence of black abalone and local topography. Consequently, the total area sampled varied among sites and ranged from $30 \mathrm{~m}^{2}$ at Stairs to $123 \mathrm{~m}^{2}$ at Government Point. Sites were sampled in the early spring (usually February to March) and late autumn (usually October to November) of each year, and an additional sample was taken at some sites in May 1995. Occasionally, we could not sample at a particular site because of logistical difficulties or storms. One plot at Government Point could not be reliably sampled, so data from this plot were excluded. Two plots were destroyed during storms (1 at Stairs in spring 1998 and 1 at Piedras Blancas in spring 2000). Therefore, an additional plot with similar abundances of abalone to the one that had been destroyed was added at each of these sites, and the abundance of black abalone was subsequently counted in these new plots and the 2 original plots that had not been damaged.

At each sampling time, the permanent plots were thoroughly searched (using a flashlight in crevices) for black abalone. Black abalone in each plot were counted, and their maximal lengths were measured to the nearest $5 \mathrm{~mm}$ for those $<40 \mathrm{~mm}$ and to the nearest $10 \mathrm{~mm}$ for those $>40 \mathrm{~mm}$, without removing them from the substratum. The lengths of occasional individuals lodged deeply in crevices had to be estimated by eye. Evidence of withering syndrome at a site was collected by observing abalone for clinical signs of the disease and noting recent accumulations of abalone shells, which would rule out declines due to poaching. The abundance of black abalone at each site was estimated as the total number of individuals found in all 3 plots. To determine whether the decline of black abalone was dependent on their size, individuals were placed into 4 categories based on their maximal shell lengths: (1) $<50 \mathrm{~mm}$ or juveniles (see Leighton \& Boolootian 1963); (2) 50 to $90 \mathrm{~mm}$ or small adults; (3) 91 to $126 \mathrm{~mm}$ or large adults; and (4) >126 mm or harvestable adults, although recreational (individuals $>126 \mathrm{~mm}$ ) and commercial (individuals $>145 \mathrm{~mm}$ ) harvesting of black abalone was banned throughout California in 1993. Linear regression analyses of abalone number (trans-

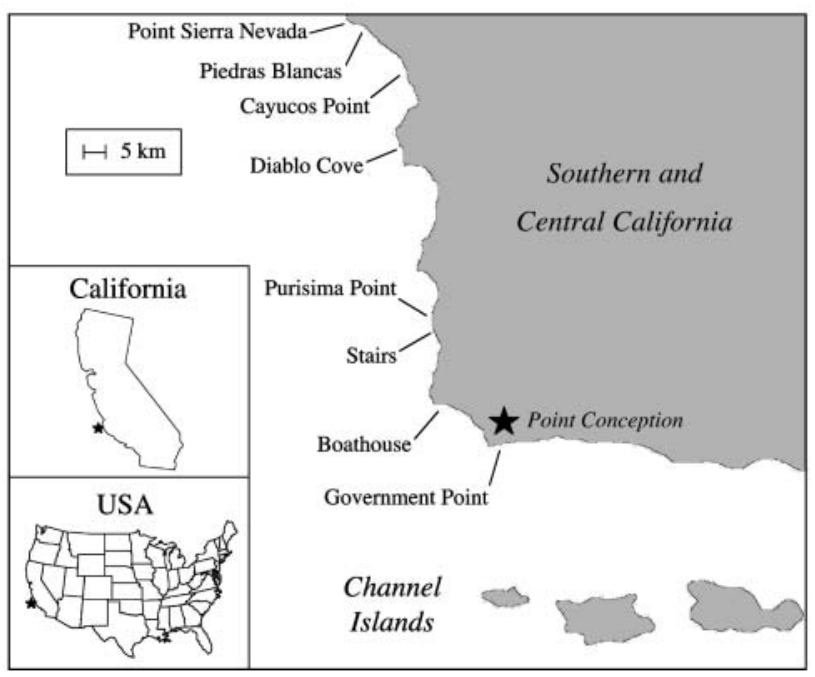

Fig. 1. Location of monitoring sites along the coast of central California, USA 
formed to their natural logarithms) versus time for juveniles, small adults, large plus harvestable adults, and all size categories together were used to assess increases or decreases in the population abundance at each site.

Sea surface temperatures were obtained from satellite data (West Coast Regional Node, CoastWatch, National Oceanic and Atmospheric Administration or NOAA; http://coastwatch.noaa.gov). Data presented are monthly means and anomalies relative to monthly means of sea surface temperatures from January 1992 to April 2001 for the 7 sites across the region extending from Government Point in the south to Point Sierra Nevada in the north. Although these data may not accurately reflect the absolute seawater temperatures experienced by black abalone in the intertidal zone (which are likely to be more extreme), they parallel data collected from coastal buoys in the region (National Data Buoy Center, National Weather Service, NOAA; http://ndbc.noaa.gov), and provide a good relative measure of seawater temperatures over time.

To determine whether declines of black abalone were exclusively associated with El Niño events, a paired $t$-test was used to compare percent changes in the abundance of adult abalone $(\geq 50 \mathrm{~mm})$ for $2 \mathrm{yr}$ periods either during or not during an El Niño event for each of the 5 sites where this was possible (1992 to 1994 versus 1994 to 1996 for Boathouse, 1992 to 1994 versus1995 to 1997 for Stairs, 1995 to 1997 versus 1997 to 1999 for Purisima Point, and 1997 to 1999 versus 1999 to 2001 for Piedras Blancas and Point Sierra Nevada). To compare the rates of decline of adult abalone during El Niño and non-El Niño years, we plotted 'survivorship' curves for the local population at each site by considering the peak abundance of abalone to be equal to the average number of individuals at a given site in the $2 \mathrm{yr}$ prior to the onset of decline. The onset of abalone decline at a given site was assessed retrospectively by considering changes in abalone number and the appearance of withering syndrome. The onset of decline was judged to be between spring and autumn 1992 for Government Point, autumn 1994 and spring 1995 for Boathouse, spring and autumn 1995 for Stairs, and spring and autumn 1998 for Purisima Point and Cayucos Point. There was a decline between spring and autumn 1992 at Boathouse, but this did not appear to be related to withering syndrome and is likely a sampling artifact. Although evidence of withering syndrome was not apparent at Piedras Blancas and Point Sierra Nevada, we decided to plot data for these sites because minor declines were observed between spring and autumn 1998. To determine whether the rates of decline of adult abalone were greater during El Niño events than in non-El Niño years, an independent $t$-test was used to compare the time it took for the abundance of adult abalone to decline to $10 \%$ of its peak value (indicating a mass mortality) for 2 sites where declines occurred during El Niño events (Government Point and Purisima Point) and 2 sites where die-offs occurred in nonEl Niño years (Boathouse and Stairs).

\section{RESULTS}

Dramatic declines in the abundance of black abalone were observed at the 5 southernmost sites, but not at the 2 northernmost sites (Fig. 2). For all sizes of abalone combined, there were significant negative slopes at the 5 southernmost sites, no detectable change in slope at Piedras Blancas and a positive slope at Point Sierra Nevada (Table 1). Numbers at impacted sites were reduced by $>90 \%$, whereas abundances at Piedras Blancas declined only slightly and those at Point Sierra Nevada increased. Abalone showed clinical signs of withering syndrome at all sites where mass mortalities occurred, and accumulations of fresh shells were observed during and after the declines. At sites with massive die-offs, significant declines occurred in all size categories (Fig. 2, Table 1). The only 2 exceptions were at sites where few individuals were present in a given size category (large and harvestable adults at Cayucos Point, juveniles at Government Point); however, the trends were the same. At both Piedras Blancas and Point Sierra Nevada, there was a significant increase in the number of juveniles over time but not in the larger size categories (Fig. 2, Table 1).

The progression of the onset of mass mortalities proceeded from south to north, without exception, but the rates of northward spread were variable among years (Figs. 1 \& 2). Large die-offs of abalone were first observed at the southernmost site, Government Point, from 1992 to 1993. Declines at Boathouse, the next most northerly site, were more gradual and started in 1995 following years of relatively stable abundances. After a period of recruitment in the mid-1990s, abalone numbers at Stairs decreased in 3 steps during the spring and summer of 1995, 1996 and 1997. During this time, the abundance of abalone at Purisima Point, less than $5 \mathrm{~km}$ north of Stairs, remained constant. After the onset of the 1997 to 1998 El Niño, however, abalone numbers at Purisima Point and Cayucos Point, a site $10 \mathrm{~s}$ of $\mathrm{km}$ to the north and near Diablo Cove, declined precipitously. In contrast, abundances of adult abalone at the 2 most northerly sites, Piedras Blancas and Point Sierra Nevada, decreased only slightly at this time. Overall abalone abundance at these 2 northern sites subsequently increased due to recruitment in the late 1990s. In contrast, new recruits or juveniles were rarely observed at sites that had experienced mass 


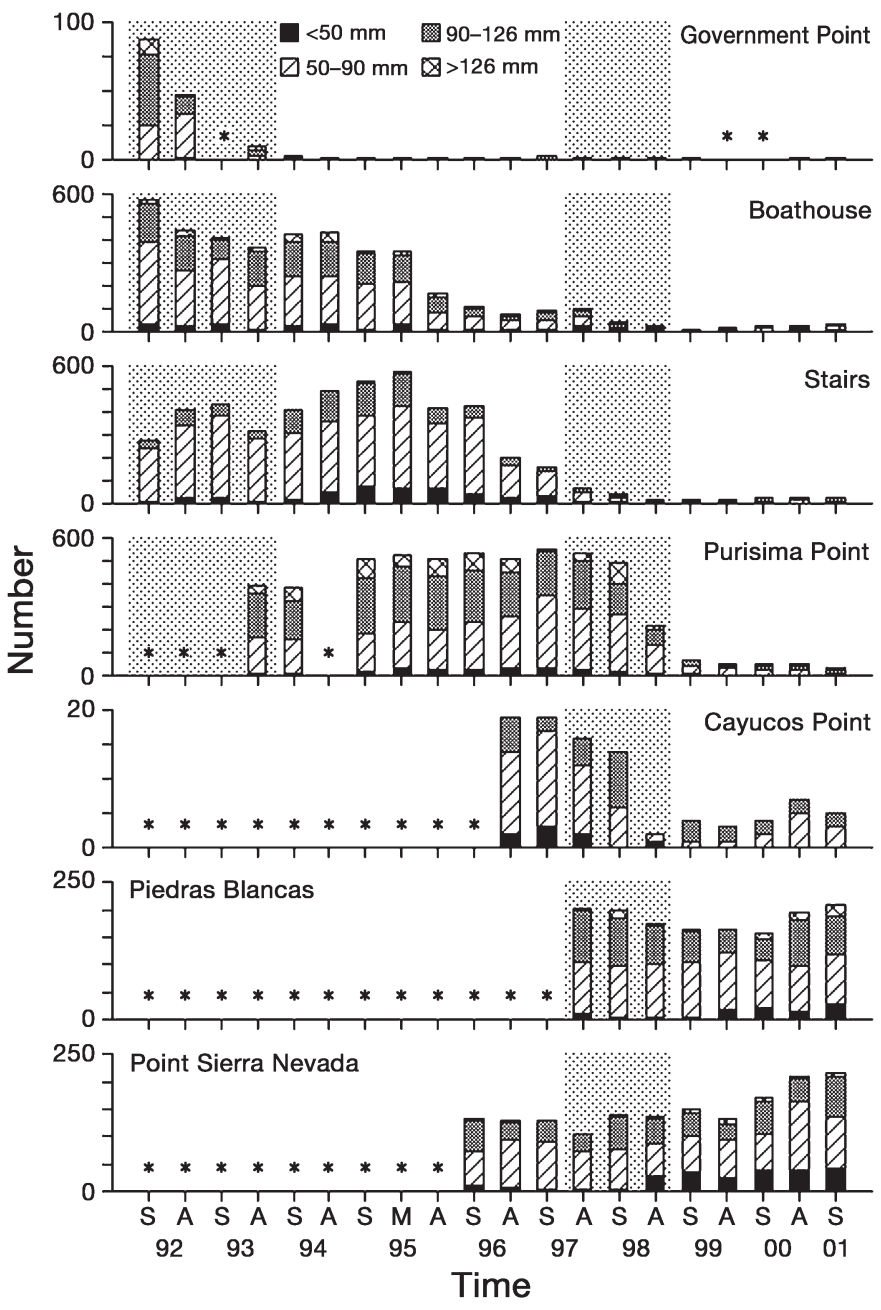

Fig. 2. Haliothis cracherodii. Changes in number of black abalone for each of 4 size classes $(<50 \mathrm{~mm}$ or juveniles, 50 to 90 $\mathrm{mm}$ or small adults, 91 to $126 \mathrm{~mm}$ or large adults, and $>126 \mathrm{~mm}$ or harvestable adults) at 7 sites (arranged from south, Government Point, to north, Point Sierra Nevada) from 1992 to 2001. Note differences in scale of the $y$-axis. Sampling was done in spring (S) and autumn (A) of each year, with an additional sample in May (M) 1995; the asterisks indicate that sampling was not done at that time. Shading indicates periods of elevated seawater temperatures due to the El Niño events of 1991 to 1993 and 1997 to 1998. Data from Government Point, Boathouse, Stairs and Purisima Point between spring 1992 and autumn

1995 have previously been reported in Altstatt et al. (1996)

mortalities and, consequently, the local populations of abalone have not recovered.

Periods of elevated sea surface temperatures (positive sea surface temperature anomalies) were associated with El Niño events (Fig. 3). Sea surface temperatures were lowest during non-El Niño periods from 1994 to 1996 (a relatively neutral period) and 1999 to 2001 (a La Niña period), intermediate during the relatively moderate and prolonged El Niño of 1991 to 1993, which began in late 1991 and extended into 1993, and were highest during the strong El Niño of 1997 to 1998. Temperatures at the southernmost sites, Government Point and Boathouse, were on average about $0.35^{\circ} \mathrm{C}$ higher than those at Stairs and Purisima Point, which were on average about $0.45^{\circ} \mathrm{C}$ higher than those at the northernmost sites, Cayucos Point, Piedras Blancas and Point Sierra Nevada. Average monthly sea surface temperatures across all sites never exceeded $17^{\circ} \mathrm{C}$ in non-El Niño years, but they remained above this level for prolonged periods during El Niño events (Fig. 3). During the 1991 to 1993 El Niño, temperatures at all sites exceeded $17^{\circ} \mathrm{C}$ for several month in the late summer and autumn in 1992 and 1993, and they reached $18^{\circ} \mathrm{C}$ at the 2 southernmost sites. During the 1997 to $1998 \mathrm{El}$ Niño, average temperatures attained $19^{\circ} \mathrm{C}$ across all sites and more than $20^{\circ} \mathrm{C}$ at the southernmost site. Importantly, temperatures remained above $18^{\circ} \mathrm{C}$ for at least 4 mo during 1997 and did not drop below $14^{\circ} \mathrm{C}$ during the winter before peaking again in late summer and early autumn 1998.

Adult abalone did not always decline during periods of elevated sea surface temperatures due to El Niño. For example, abalone numbers declined at Government Point during the 1991 to 1993 El Niño, but they
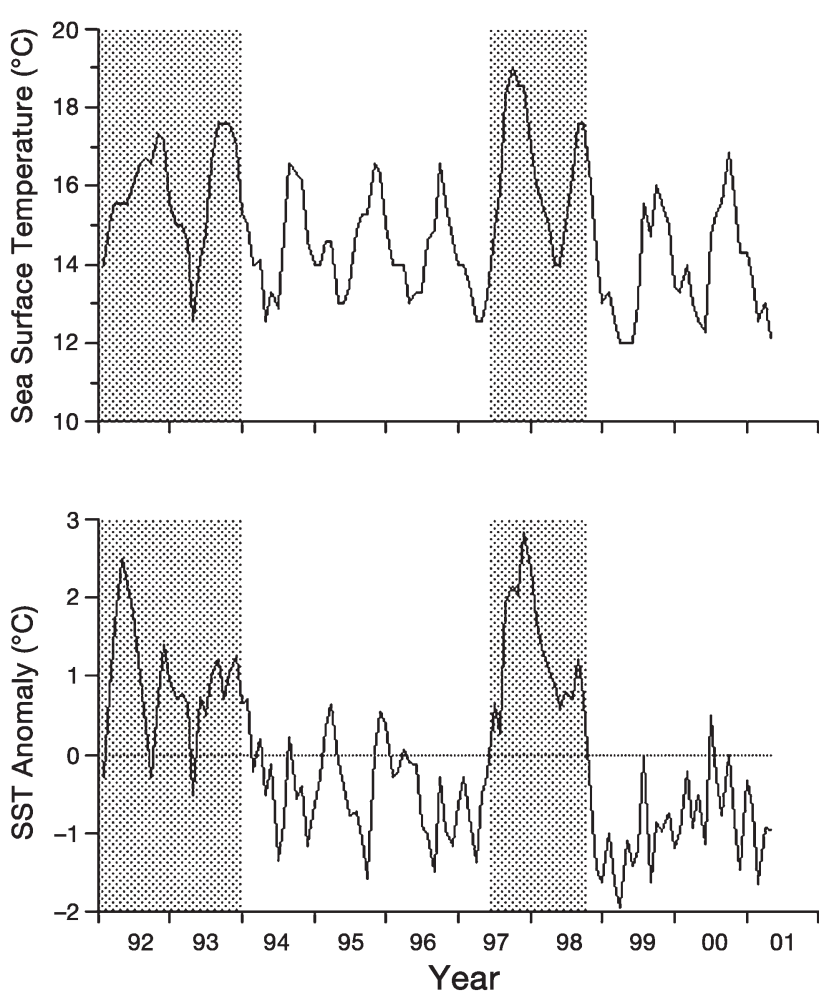

Fig. 3. Changes in monthly means and anomalies relative to monthly means of sea surface temperatures $\left(\mathrm{SST},{ }^{\circ} \mathrm{C}\right)$ from January 1992 to April 2001. Shading indicates periods of elevated seawater temperatures due to the El Niño events of 1991 to 1993 and 1997 to 1998 
Table 1. Haliothis cracherodii. Results of linear regression analyses (model: $\ln [$ number +1$]=$ slope[time] + intercept) of changes in numbers of black abalone in each of 4 size categories at 7 sites over time (time is measured in mo [Month 1], from January 1992 to March 2001 [Month 111]). $t$ : $t$-statistic

\begin{tabular}{|c|c|c|c|c|c|c|}
\hline Size category and site & Intercept & Slope & $\mathrm{r}^{2}$ & $t$ & $\mathrm{p}$ & $\mathrm{n}$ \\
\hline \multicolumn{7}{|l|}{ All abalone } \\
\hline Government Point & 2.88 & -0.026 & 0.56 & -4.4 & $<0.001$ & 17 \\
\hline Boathouse & 6.72 & -0.035 & 0.86 & -11.0 & $<0.001$ & 20 \\
\hline Stairs & 6.91 & -0.036 & 0.77 & -7.7 & $<0.001$ & 20 \\
\hline Purisima Point & 7.57 & -0.032 & 0.68 & -5.5 & $<0.001$ & 16 \\
\hline Cayucos Point & 4.48 & -0.028 & 0.49 & -2.8 & 0.024 & 10 \\
\hline Piedras Blancas & 5.24 & -0.000 & 0.00 & -0.1 & 0.920 & 8 \\
\hline Point Sierra Nevada & 4.29 & 0.008 & 0.60 & 3.7 & 0.005 & 11 \\
\hline \multicolumn{7}{|c|}{ Large and harvestable adults (>90 mm) } \\
\hline Government Point & 2.45 & -0.021 & 0.54 & -4.2 & $<0.001$ & 17 \\
\hline Boathouse & 5.76 & -0.035 & 0.82 & -9.1 & $<0.001$ & 20 \\
\hline Stairs & 4.79 & -0.025 & 0.55 & -4.7 & $<0.001$ & 20 \\
\hline Purisima Point & 7.10 & -0.036 & 0.74 & -6.3 & $<0.001$ & 16 \\
\hline Cayucos Point & 2.24 & -0.012 & 0.13 & -2.3 & 0.306 & 10 \\
\hline Piedras Blancas & 4.69 & -0.004 & 0.04 & -0.5 & 0.639 & 8 \\
\hline Point Sierra Nevada & 3.39 & 0.006 & 0.18 & 1.4 & 0.200 & 11 \\
\hline \multicolumn{7}{|c|}{ Small adults (50 to $90 \mathrm{~mm}$ ) } \\
\hline Government Point & 1.84 & -0.023 & 0.41 & -3.2 & 0.006 & 17 \\
\hline Boathouse & 6.15 & -0.036 & 0.89 & -12.0 & $<0.001$ & 20 \\
\hline Stairs & 6.69 & -0.039 & 0.82 & -9.1 & $<0.001$ & 20 \\
\hline Purisima Point & 6.48 & -0.027 & 0.57 & -4.3 & $<0.001$ & 16 \\
\hline Cayucos Point & 3.99 & -0.028 & 0.40 & -2.3 & 0.050 & 10 \\
\hline Piedras Blancas & 4.74 & -0.002 & 0.16 & -1.1 & 0.322 & 8 \\
\hline Point Sierra Nevada & 4.02 & 0.004 & 0.12 & 1.1 & 0.298 & 11 \\
\hline \multicolumn{7}{|l|}{ Juveniles (<50 mm) } \\
\hline Government Point & 0.14 & -0.002 & 0.13 & -1.5 & 0.162 & 17 \\
\hline Boathouse & 3.40 & -0.020 & 0.38 & -3.3 & 0.004 & 20 \\
\hline Stairs & 4.25 & -0.032 & 0.52 & -4.4 & 0.003 & 20 \\
\hline Purisima Point & 4.27 & -0.032 & 0.43 & -3.2 & 0.006 & 16 \\
\hline Cayucos Point & 2.64 & -0.026 & 0.66 & -3.9 & 0.005 & 10 \\
\hline Piedras Blancas & -0.54 & 0.033 & 0.58 & 2.9 & 0.029 & 8 \\
\hline Point Sierra Nevada & -0.31 & 0.037 & 0.54 & 3.2 & 0.010 & 11 \\
\hline
\end{tabular}

increased at Stairs during this same interval (Fig. 2). In addition, declines of black abalone were not exclusively associated with periods of El Niño: percent changes in the abundance of adult abalone did not differ significantly during El Niño events and non-El Niño years (paired $t$-test: $t=-0.33, \mathrm{p}>0.75, \mathrm{df}=4$ ). Abalone at Boathouse and Stairs declined during non-El Niño years, whereas those at Government Point, Purisima Point and Cayucos Point declined during El Niño events (Fig. 2). The only consistent patterns were that the abundance of adult abalone declined at all sites during the 1997 to 1998 El Niño (although only slightly at Piedras Blancas and Point Sierra Nevada), when sea surface temperatures were highest, and did not decline at any site during the 1999 to 2001 La Niña, when sea surface temperatures were lowest (Figs. 2 \& 3). The rates of decline of adult abalone were also variable among sites, but declines during El Niño events were faster than those during non-El Niño years (Fig. 4). Declines at Boathouse and Stairs, which occurred during non-El Niño years in the mid-1990s, were slowest, taking on average 27 mo for their abundances to be reduced to below $25 \%$ of their peak levels (Fig. 4). The rate of decline at Government Point during the 1991 to 1993 El Niño was intermediate, with levels dipping $25 \%$ below peak abundances in less than $19 \mathrm{mo}$, and fastest at Purisima Point and Cayucos Point during the 1997 to 1998 El Niño, where abalone numbers were reduced to about $25 \%$ of their peak abundances in less than 12 mo (Fig. 4). Indeed, mass mortalities (i.e. reductions to below $10 \%$ of peak abundance) occurred significantly faster (independent $t$-test, $t=12.0, \mathrm{p}<0.01$, $\mathrm{df}=2)$ during El Niño events $(24 \pm 1 \mathrm{mo}$, mean $\pm \mathrm{SE}$ for Government Point and Purisima Point) than during non-El Niño years $(41 \pm 1 \mathrm{mo}$, mean $\pm \mathrm{SE}$ for Boathouse and Stairs).

\section{DISCUSSION}

Surveys reveal that mass mortalities of black abalone due to withering syndrome are progressing northward up the mainland coast of central California. These results confirm the observations of Altstatt et al. 

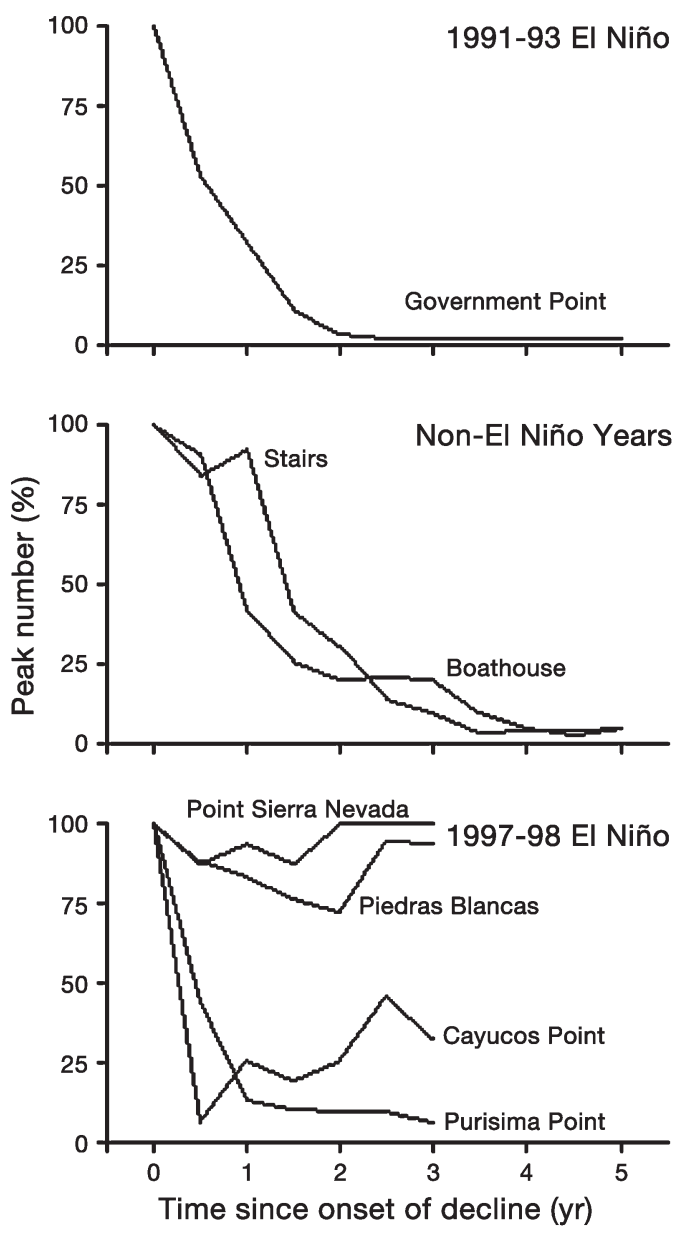

Fig. 4. Haliothis cracherodii. Declines in the numbers of adult ( $\geq 50 \mathrm{~mm}$ ) black abalone since the onset of the decline during the 1991 to 1993 El Niño event (Government Point), non-El Niño years (Boathouse, Stairs) and the 1997 to 1998 El Niño event (Cayucos Point, Purisima Point, Point Sierra Nevada and Piedras Blancas). Note that abundances at Point Sierra Nevada 2 yr after the onset of decline were plotted as 100\% even though they exceeded the initial peak abundance

(1996) that mortalities of black abalone were spreading northward from Point Conception. Populations of black abalone at Government Point, Boathouse and Stairs, which had declined or were in decline by 1995 (Altstatt et al. 1996), continued to decline and have not recovered. By 1998, abalone at 2 more northerly sites, Purisima Point and Cayucos Point, were hit by massive die-offs. Although these spatial patterns of decline suggest that the disease is gradually moving northward, the timing of the onset of declines was highly variable. For example, progression of the mass mortalities between Boathouse and Stairs, which are separated by more than $20 \mathrm{~km}$, took about $1 \mathrm{yr}$ (Altstatt et al. 1996), whereas it took about 2 yr for mass mortalities to be observed at Purisima Point, which is less than $5 \mathrm{~km}$ north of Stairs. Moreover, declines at Cayucos
Point, which is more than $50 \mathrm{~km}$ north of Stairs, were coincidental with those at Purisima Point. These temporal patterns of decline suggest that the incidence of disease and the onset of mass mortalities may not be simply due to the gradual northward progression of the pathogen causing withering syndrome (Altstatt et al. 1996). Withering syndrome was observed at Government Point and near Cayucos Point years before the mass mortalities (Altstatt et al. 1996), and recent surveys have shown that isolated cases of withering syndrome are present in black abalone at sites as far north as the San Francisco area (Altstatt et al. 1996, Andree et al. 2000, authors' pers. obs.). It is possible that red abalone Haliotis rufescens, which also exhibit clinical signs of withering syndrome (Moore et al. 2000), from commercial farms along the mainland coast of central California, may transmit the disease to intertidal populations of black abalone, but whether this occurs is unknown. Consequently, determining the pattern of spread of the causative agent may be confounded by anthropogenic influences. There does appear, however, to be a lag between the incidence of withering syndrome in a local population of black abalone and its subsequent demise due to the disease. The patterns of mass mortality of black abalone still appear to follow this south-to-north progression, suggesting that seawater temperature or some other factor related to latitude may trigger the onset of declines.

Whether elevated sea surface temperatures due to El Niño events are responsible for the onset of mass mortalities of black abalone remains equivocal. Numbers declined at Government Point during the moderate and prolonged 1991 to 1993 El Niño, but they increased at Stairs. Moreover, mortalities were not exclusively associated with El Niño years, as massive die-offs of black abalone were observed at Boathouse and Stairs in non-El Niño years during the mid-1990s. During the strong 1997 to 1998 El Niño, we predicted that if increased seawater temperatures triggered massive die-offs of black abalone, then abalone numbers at all sites that had not yet experienced mass mortalities should decline simultaneously, because each of these sites would be influenced by the same mass of warm water. The abundance of adult abalone did indeed decline at all sites, but mass mortalities occurred only at the 2 southernmost sites, Purisima Point and Cayucos Point, and numbers at the 2 more northern sites, Piedras Blancas and Point Sierra Nevada, decreased only slightly. This difference might be because the pathogen causing withering syndrome may have been present at Purisima Point and Cayucos Point, but absent from Piedras Blancas and Point Sierra Nevada. Withering syndrome was observed at a site near Cayucos Point in 1995, and Purisima Point is near Stairs, which had already undergone massive die-offs due to 
withering syndrome. In contrast, there was no evidence of diseased abalone at the 2 northernmost sites. Therefore, elevated sea surface temperatures due to El Niño may have triggered mass mortalities at the 2 southern sites because the pathogen was already present or near threshold numbers in the local populations.

Although mass mortalities of black abalone do not appear to depend on increased seawater temperatures associated with El Niño, local populations of abalone declined faster during El Niño events than during nonEl Niño periods, particularly the strong 1997 to 1998 El Niño. Sea surface temperatures during the 1997 to $1998 \mathrm{El}$ Niño exceeded $18^{\circ} \mathrm{C}$ for 4 mo (also observed at the southern sites during the 1991 to 1993 El Niño), and temperatures may have been higher in the intertidal region where black abalone live. Laboratory experiments have shown that apparently healthy black abalone exhibit substantially increased mortality when subjected to temperatures of $18^{\circ} \mathrm{C}$ for 6 mo compared to ambient seawater temperatures of 10 to $14^{\circ} \mathrm{C}$ (Steinbeck et al. 1992). Additionally, elevated seawater temperatures promoted the development of withering syndrome in black abalone already exhibiting clinical signs of the disease (Friedman et al. 1997, see also Moore et al. 2000 for comparable results with Haliotis rufescens). Further, Moore et al. (2000) reported that commercial abalone farmers observe an increased incidence of withering syndrome in red abalone $H$. rufescens when seawater temperatures reach $18^{\circ} \mathrm{C}$, and during the 1997 to 1998 El Niño they reported unusually high numbers of individuals with signs of withering syndrome. In contrast, sea surface temperatures hardly rose above $16^{\circ} \mathrm{C}$ during non-El Niño years. Consequently, prolonged thermal stress in combination with the presence of the pathogen may promote the development of withering syndrome and accelerate the massive die-offs of black abalone (Lafferty \& Kuris 1993).

The mechanisms by which black abalone acquire withering syndrome and transmit the disease, and how individual cases lead to widespread mortality of a local population, are still uncertain and likely complex. The pathogen causing withering syndrome may incubate for many months before clinical signs are evident in the field (Friedman et al. 1997, Andree et al. 2000), making it difficult to assign causation. At the local scale of a site, the prevalence and rate of transmission of the disease, which may be directly communicable among individuals (Gardner et al. 1995, Friedman et al. 1997), likely increases as the pathogen reproduces within infected individuals. Mass mortalities at a site may then occur once the levels of bacteria reach a critical threshold within the local population. Stressors such as elevated water temperatures during El Niño may increase the prevalence of the pathogen, the susceptibility of abalone to infection, and the rate at which bacteria reproduce within and are transmitted among individuals at a site (Harvell et al. 1999). This study has not, however, shown a causative link between elevated seawater temperatures during El Niño and the rate of decline of abalone. Mortality may indeed proceed indirectly through other stresses (e.g. starvation), which may or may not be related to El Niño (Tissot 1990, 1995, Davis et al. 1992, Richards \& Davis 1993). It has been suggested that the removal of natural predators (e.g. sea otters) and a ban on the harvesting of black abalone may have dramatically increased the local densities of abalone, thus increasing intraspecific competition and the opportunity for transmission of the disease (Davis et al. 1992). Such stresses, coupled with potential reductions in the availability of food and increased seawater temperatures during El Niño, may ultimately lead to the decline of local populations of black abalone (Davis et al. 1992). Indeed, elevated seawater temperatures, such as those associated with El Niño events, have been implicated in the demise of several commercially and ecologically important species of marine benthic invertebrates (e.g. Engle 1994, Scheibling \& Hennigar 1997, Eckert et al. 2000). Other natural and anthropogenic stresses, particularly those that elevate water temperatures (e.g. thermal discharges, global warming), would also be expected to accelerate the spread of withering syndrome and mass mortalities throughout populations of black abalone along the coast of California (Tissot 1995). With the increase in the frequency and duration of El Niño events in recent decades (Trenberth \& Hoar 1996, Fedorov \& Philander 2000) and the escalation of anthropogenic disturbance along the world's coastlines, disease is expected to play an increasingly important role in structuring ecological communities at local and global scales (Harvell et al. 1999).

Black abalone play an important ecological role in coastal communities and once formed an important commercial and recreational fishery (Davis et al. 1992). The prognosis for rapid, natural recovery of black abalone populations along the southern and central coasts of California is not good, and in 1999 Haliotis cracherodii was listed as a candidate species for protection under the USA Endangered Species Act. Withering syndrome has already been observed in black abalone at other sites along the central coast and extending toward northern California (authors' pers. obs.) and, therefore, mass mortalities in these regions are likely. The disease affects all size classes of individuals. Few healthy abalone remain at sites where massive die-offs have occurred, and there has been little successful recruitment subsequent to the declines (Richards \& Davis 1993, VanBlaricom et al. 1993, Tissot 
1995; see also Miller \& Lawrenz-Miller 1993). The lack of recruits may reflect unsuccessful spawning due to low densities of adults (Breen \& Adkins 1980), limited larval dispersal (Prince et al. 1988, Hamm \& Burton 2000), alteration of suitable habitat for recruitment as space previously occupied by adult abalone is colonized by other species (Miller \& Lawrenz-Miller 1993, Lafferty \& Kuris 1993, Altstatt et al. 1996) or the continued but undetected presence of disease at these sites. Similar to other species of abalone (Prince et al. 1987, 1988, McShane 1992), recruitment of black abalone appears to be patchy and extremely localized. Indeed, pulses of recruitment at sites with relatively stable populations (e.g. Stairs in the mid-1990s and Point Sierra Nevada in the late 1990s) were not observed at sites only 10 s of $\mathrm{km}$ to the south, where populations had undergone mass mortalities (e.g. Government Point in the mid-1990s and Purisima Point in the late 1990s). Given these patterns of recruitment and the northward progression of mass mortalities, it appears that the replenishment of black abalone populations from natural recruitment will take decades, if it occurs at all. Consequently, intervention, such as laboratory culture, outplanting and establishment of protected areas for reproductive adults (see Wallace 1998), may eventually be needed to prevent extinction of black abalone.

Acknowledgements. We thank Jessie Altstatt, the MMS MINT Team, and numerous assistants and volunteers for help in the field. We are grateful to many people for granting access to the study sites. These include Tim King and the Bixby Ranch Corporation and Brad Lendberg and the CojoJalama Ranch (Government Point), the Vandenberg Air Force Base, especially Nancy Read and the staff at the Recreation Center (Boathouse, Stairs, and Purisima Point), the United States Geological Survey (USGS) (Piedras Blancas) and the Hearst Corporation (Point Sierra Nevada). This work was funded by a Natural Sciences and Engineering Research Council (NSERC) of Canada Postdoctoral Fellowship to T.E.M. and awards to P.T.R. from the US Department of Interior (Minerals Management Service), the UC Toxic Substances Research and Teaching Program, the National Science Foundation, and the Packard Foundation. This is contribution number 89 from PISCO, the Partnership for Interdisciplinary Studies of Coastal Oceans: A Long Term Ecological Consortium funded by the David and Lucile Packard Foundation.

\section{LITERATURE CITED}

Altstatt JM, Ambrose RF, Engle JM, Haaker PL, Lafferty KD, Raimondi PT (1996) Recent declines of black abalone Haliotis cracherodii on the mainland coast of central California. Mar Ecol Prog Ser 142:185-192

Andree KB, Friedman CS, Moore JD, Hedrick RP (2000) A polymerase chain reaction assay for the detection of genomic DNA of a Rickettsiales-like prokaryote associated with withering syndrome in California abalone. J Shellfish Res 19:213-218
Breen PA, Adkins BE (1980) Spawning in a British Columbia population of northern abalone, Haliotis kamtschatkana. Veliger 23:177-179

Davis GE, Richards DV, Haaker PL, Parker DO (1992) Abalone population declines and fishery management in southern California. In: Shepherd SA, Tegner MJ, Gusman del Proo SA (eds) Abalone of the world: biology, fisheries, and culture. Proc 1st Int Symp Abalone. Blackwell Scientific Publishers, Oxford, p 237-249

Eckert GL, Engle JM, Kushner DJ (2000) Sea star disease and population declines at the Channel Islands. In: Browne DR, Mitchell KL, Chaney HW (eds) Proc 5th Calif Islands Symp. Santa Barbara Museum of Natural History, Santa Barbara, p 390-393

Engle JM (1994) Perspectives on the structure and dynamics of nearshore marine assemblages of the California Channel Islands. In: Halvorson WL, Maender GJ (eds) 4th Calif Islands Symp: update on the status of resources. Santa Barbara Museum of Natural History, Santa Barbara, p 13-26

Fedorov AV, Philander SG (2000) Is El Niño changing? Science 288:1997-2002

Friedman CS, Thomson M, Chun C, Haaker PL, Hedrick RP (1997) Withering syndrome of the black abalone, Haliotis cracherodii (Leach): water temperature, food availability, and parasites as possible causes. J Shellfish Res 16: 403-411

Friedman CS, Andree KB, Beauchamp KA, Moore JD, Robbins TT, Shields JD, Hedrick RP (2000) 'Candidatus Xenohaliotis californiensis', a newly described pathogen of abalone, Haliotis spp., along the West Coast of North America. Int J Syst Evolut Microbiol 50:847-855

Gardner GR, Harshbarger JC, Lake JL, Sawyer TK, Price KL, Stephenson MD, Haaker PL, Togstad HA (1995) Association of prokaryotes with symptomatic appearance of withering syndrome in black abalone Haliotis cracherodii. J Invertebr Pathol 66:111-120

Haaker PL, Parker DO, Togstad H, Richards DV, Davis GE, Friedman CS (1992) Mass mortality and withering syndrome in black abalone, Haliotis cracherodii, in California. In: Shepherd SA, Tegner MJ, Gusman del Proo SA (eds) Abalone of the world: biology, fisheries, and culture. Proc 1st Int Symp Abalone. Blackwell Scientific Publishers, Oxford, p 214-224

Hamm DE, Burton RS (2000) Population genetics of black abalone, Haliotis cracherodii, along the central California coast. J Exp Mar Biol Ecol 254:235-247

Harvell CD, Kim K, Burkholder JM, Colwell RR and 9 others (1999) Emerging marine diseases-climate links and anthropogenic factors. Science 285:1505-1510

Lafferty KD, Kuris AM (1993) Mass mortality of abalone Haliotis cracherodii on the California Channel Islands: tests of epidemiological hypotheses. Mar Ecol Prog Ser 96:239-248

Leighton D, Boolootian RA (1963) Diet and growth in the black abalone Haliotis cracherodii. Ecology 44:227-238

McShane PE (1992) Early life history of abalone: a review. In: Shepherd SA, Tegner MJ, Gusman del Proo SA (eds) Abalone of the world: biology, fisheries, and culture. Proc 1st Int Symp Abalone. Blackwell Scientific Publishers, Oxford, p 203-213

Miller AC, Lawrenz-Miller SE (1993) Long-term trends in black abalone, Haliotis cracherodii Leach, 1814, populations along the Palos Verdes Peninsula, California. J Shellfish Res 12:195-200

Moore JD, Robbins TT, Friedman CS (2000) Withering syndrome in farmed red abalone, Haliotis rufescens: thermal induction and association with a gastrointestinal Rickettsiales-like prokaryote. J Aquat Anim Health 12:26-34 
Prince JD, Sellers TL, Ford WB, Talbot SR (1987) Experimental evidence for limited dispersal of haliotid larvae (genus Haliotis; Mollusca: Gastropoda). J Exp Mar Biol Ecol 106: 243-263

Prince JD, Sellers TL, Ford WB, Talbot SR (1988) Confirmation of a relationship between the localized abundance of breeding stock and recruitment for Haliotis rubra Leach (Mollusca: Gastropoda). J Exp Mar Biol Ecol 122:91-104

Richards DV, Davis GE (1993) Early warnings of modern population collapse in black abalone Haliotis cracherodii, Leach, 1814 at the California Channel Islands. J Shellfish Res 12:189-194

Scheibling RE, Hennigar AW (1997) Recurrent outbreaks of disease in sea urchins Strongylocentrotus droebachiensis in Nova Scotia: evidence for a link with large-scale meteorologic and oceanographic events. Mar Ecol Prog Ser 152:155-165

Steinbeck JR, Groff JM, Friedman CS, McDowell T, Hedrick RP (1992) Investigations into a mortality among populations of the California black abalone, Haliotis cracherodii, on the central coast of California, USA. In: Shepherd SA, Tegner MJ, Gusman del Proo SA (eds) Abalone of the world: bio-

Editorial responsibility: Lisa Levin (Contributing Editor), La Jolla, California, USA logy, fisheries, and culture. Proc 1st Int Symp Abalone. Blackwell Scientific Publishers, Oxford, p 203-213

Tissot BN (1990) El Niño responsible for decline of black abalone off southern California. Hawaiian Shell News June:3-4

Tissot BN (1995) Recruitment, growth, and survivorship of black abalone on Santa Cruz Island following mass mortality. Bull South Calif Acad Sci 94:179-189

Trenberth KE, Hoar TJ (1996) The 1990-1995 El NiñoSouthern Oscillation event: longest on record. Geophys Res Lett 23:57-60

VanBlaricom GR, Ruediger JL, Friedman CS, Woodward DD, Hedrick RP (1993) Discovery of withering syndrome among black abalone Haliotis cracherodii Leach, 1814, populations at San Nicolas Island, California. J Shellfish Res 12:185-188

Wallace SS (1998) Evaluating the effects of three forms of marine reserve on northern abalone populations in British Columbia, Canada. Conserv Biol 13:882-887

Wolter K, Timlin MS (1998) Measuring the strength of the ENSO events: how does the 1997/98 rank? Weather 53: $315-324$

Submitted: July 27, 2001; Accepted: April 5, 2002

Proofs received from author(s): October 8, 2002 